\title{
Effects of Vasopressin Antagonist on Vasopressin Binding, Adenylate Cyclase Activation, and Water Flux
}

Jin K. Kim, Mark A. Dillingham, Sandra N. Summer, San-e Ishikawa, Robert J. Anderson, and Robert W. Schrier Department of Medicine, University of Colorado Medical School, Denver, Colorado 80262

\begin{abstract}
We studied the effect of an arginine vasopressin (AVP) analogue, (1-[ $\beta$-mercapto- $\beta, \beta$-cyclopentamethylenepropionic acid $], 2-0$ ethyltyrosine,4-valine)AVP(d[CH $\left.\mathrm{CH}_{2} \mathrm{~J}_{5} \mathrm{Tyr}[\mathrm{Et}] \mathrm{VAVP}\right)$, on the stimulation of adenylate cyclase by various hormones in the isolated nephron segments and ${ }^{3} \mathrm{H}-\mathrm{AVP}$ binding to renal papillary membranes from the rat. The net water flux across the renal cortical collecting tubules of the rabbit was also examined. We found that $\mathrm{d}\left(\mathrm{CH}_{2}\right)_{5} \mathrm{Tyr}(\mathrm{Et})$ VAVP significantly inhibited adenylate cyclase activation by AVP in cortical, medullary, and papillary collecting tubules and in the medullary thick ascending limb. In contrast, the AVP analogue did not alter the stimulation of adenylate cyclase by parathyroid hormone in the cortical thick ascending limb, by glucagon in the medullary thick ascending limb, and by calcitonin in cortical collecting tubules. In addition, d $\left(\mathrm{CH}_{2}\right)_{5} \mathrm{Tyr}(\mathrm{Et})$ VAVP blocked $\left[{ }^{3} \mathrm{H}\right] A$ VP binding to renal papillary membranes. The enhanced net water transport induced by AVP in isolated, perfused rabbit cortical collecting tubules also was completely blocked by this AVP analogue. These results indicate that $\mathrm{d}\left(\mathrm{CH}_{2}\right)_{5} \mathrm{Tyr}(\mathrm{Et}) \mathrm{VAVP}$ specifically antagonizes the cellular action of AVP on the medullary thick ascending limb and on the cortical, medullary, and papillary collecting tubules. Evidence is also presented for competitive antagonism as the cellular mechanism of action.
\end{abstract}

\section{Introduction}

A specific antagonist of the antidiuretic action of arginine vasopressin (AVP) ${ }^{1}$ has recently been synthesized by Manning et al. (1). This AVP analogue, (1-[ $\beta$-mercapto- $\beta, \beta$-cyclopentamethylenepropionic acid],2 - O - ethyltyrosine, 4 - valine)AVP(d$\left.\left(\mathrm{CH}_{2}\right)_{5} \mathrm{Tyr}(\mathrm{Et}) \mathrm{VAVP}\right)$, inhibited the antidiuretic response to exogenous and endogenous AVP in the absence of changes in glomerular filtration rate, solute excretion, and blood pressure in the rat $(2,3)$. In vitro studies in pig and human medullary membranes have also shown that the AVP analogue inhibits vasopressin binding $(4,5)$. Since there is a $5: 1$ ratio of thick ascending

Received for publication 5 June 1985.

1. Abbreviations used in this paper: AVP, arginine vasopressin; $\mathrm{d}\left(\mathrm{CH}_{2}\right)_{5} \mathrm{Tyr}(\mathrm{Et})$ VAVP, (1-[ $\beta$-mercapto- $\beta, \beta$-cyclopentamethylenepropionic acid]2,0-ethyltyrosine,4-valine)AVP; CAL, thick ascending limb of Henle's loop from cortex; CCT, cortical collecting tubules; $L_{\mathrm{p}}$, hydraulic water conductivity in $\mathrm{cm} / \mathrm{s} \cdot \mathrm{atm}$; MAL, thick ascending limb of Henle's loop from medulla; MCT, medullary collecting tubules; PCT, papillary collecting tubules; PTH, parathyroid hormone; SCT, salmon calcitonin.

J. Clin. Invest.

(c) The American Society for Clinical Investigation, Inc.

$0021-9738 / 85 / 10 / 1530 / 06 \$ 1.00$

Volume 76, October 1985, 1530-1535 limbs to collecting tubules in such medullary membrane preparations, a specific effect of the analogue on adenylate cyclase response of medullary collecting tubules (MCT) and papillary collecting tubules (PCT) cannot be ascertained from these studies.

The present study was undertaken to further characterize the cellular action of this AVP antagonist. Specifically, the effect of the AVP antagonist was examined on $(a){ }^{3} \mathrm{H}$-AVP binding to rat papillary membranes, on $(b)$ the activation of adenylate cyclase by AVP, parathyroid hormone (PTH), calcitonin, and glucagon in specific rat nephron segments, including collecting tubule and thick ascending limb segments, and on $(c)$ water flux across isolated perfused rabbit cortical collecting tubules (CCT). Taken together, the results of these in vitro experiments indicate that the AVP analogue is a specific inhibitor of the cellular action of AVP in the medullary thick ascending limb, CCT, MCT, and PCT of the rat. A specific inhibition of AVP-induced water flux across the isolated perfused CCT of the rabbit was also demonstrated. Evidence is presented in support of competitive antagonism as the cellular mechanism of action.

\section{Methods}

Microdissection of tubules. Male Sprague-Dawley rats (200-250 g body weight) were lightly anesthetized with pentobarbital $(3 \mathrm{mg} / 100 \mathrm{~g}$ body weight) and the left kidney was perfused with $10 \mathrm{ml}$ of collagenase me$\operatorname{dium}\left(137 \mathrm{mM} \mathrm{NaCl}, 5 \mathrm{mM} \mathrm{KCl}, 0.8 \mathrm{mM} \mathrm{MgSO}_{4}, 0.8 \mathrm{mM} \mathrm{Na}_{2} \mathrm{HPO}_{4}\right.$, $1 \mathrm{mM} \mathrm{MgCl}, 0.25 \mathrm{mM} \mathrm{CaCl}_{2}, 10 \mathrm{mM}$ Tris, pH 7.4, $10-20 \mathrm{U} / \mathrm{ml}$ collagenase [Millipore Corp., Greenhold, $\mathrm{NJ}$ ], $1 \mathrm{mg} / \mathrm{ml}$ hyaluronidase [Sigma Chemical Co., St. Louis, MO], and $1 \mathrm{mg} / \mathrm{ml}$ bovine serum albumin with $20 \mathrm{U} / \mathrm{ml}$ heparin) at an infusion rate of $1 \mathrm{ml} / \mathrm{min}$. The cortical, medullary, and papillary tissue was dissected and sliced to thin strips with direction from cortex to papillary tip. Then the pieces were incubated in an aerated collagenase medium for $60 \mathrm{~min}$ for papillary tissue and $30 \mathrm{~min}$ for cortical and medullary tissues at $35^{\circ} \mathrm{C}$. After incubation the tissues were washed with cold microdissection medium (same as the collagenase medium, except with $1 \mathrm{mM} \mathrm{CaCl}$ and no collagenase, hyaluronidase, or bovine serum albumin) and kept on ice while microdissection was performed. CCT, MCT, and PCT, as well as the thick ascending limb of Henle's loop from cortex (CAL) and medulla (MAL), were dissected under a stereomicroscope using thin needles. Dissected tubules were transferred to a concave bacteriological slide by aspiration of tubules in a small droplet of microdissection medium. The tubules were then photographed to measure the lengths. The tubules were disrupted by hypoosmotic shock and freezing. After the microdissection, medium was aspirated off, 0.5 $\mu 1$ hypoosmotic medium ( $1 \mathrm{mM} \mathrm{MgCl}, 0.25 \mathrm{mM}$ EDTA, $0.1 \%$ bovine serum albumin, and $1 \mathrm{mM}$ Tris, $\mathrm{pH}$ 7.4) was added under the microscope; the samples were then frozen immediately by placing them on a block of dry ice. The frozen tubules were thawed once and refrozen, then kept at $-80^{\circ} \mathrm{C}$ until assayed. The basal and hormone-stimulated activities of adenylate cyclase were stable at least for $5 \mathrm{~d}$ at $-80^{\circ} \mathrm{C}$.

Assays of adenylate cyclase and cAMP-phosphodiesterase activity on tubules. The activity of adenylate cyclase was measured according to a modification (6) of the method of Morel et al. (7). Slides with tubules (1.5-2 $\mathrm{mm}$ total tubule length per sample) were incubated at $37^{\circ} \mathrm{C}$ for $30 \mathrm{~min}$ in a final volume of $5.5 \mu \mathrm{l}$ containing $0.25 \mathrm{mM} \alpha-\left[{ }^{32} \mathrm{P}\right] \mathrm{ATP}$ (4 to $5 \times 10^{6} \mathrm{cpm} / \mathrm{sample}$ ), $1 \mathrm{mM}$ cAMP, $3.8 \mathrm{mM} \mathrm{MgCl}, 0.25 \mathrm{mM}$ EDTA, 
$20 \mathrm{mM}$ creatine phosphate (Calbiochem-Behring, Corp., San Diego, CA), $200 \mathrm{U} / \mathrm{ml}$ creatine phosphokinase (Calbiochem-Behring, Corp.), and 100 $\mathrm{mM}$ Tris, pH 7.4, with or without addition of hormone (AVP [Bachem, Torrance, CA]; glucagon and salmon calcitonin [Calbiochem-Behring, Corp.]; PTH [Beckman, Palo Alto, CA]) or AVP analogue, $\mathrm{d}\left(\mathrm{CH}_{2}\right)_{5}$ Tyr(Et)VAVP, or both together. The reaction mixture was sealed between two vaseline-coated concave slides and immersed in a water bath. The reaction was stopped by addition of $150 \mu$ l stopping solution $(3.3 \mathrm{mM}$ ATP, $5 \mathrm{mM}$ cAMP, $50 \mathrm{mM}$ Tris- $\mathrm{HCl}$, $\mathrm{pH} 7.6$, and $\left[{ }^{3} \mathrm{H}\right] \mathrm{cAMP}$ containing $1 \times 10^{4} \mathrm{cpm} /$ sample to determine recovery). Produced [ $\left.{ }^{32} \mathrm{P}\right]$ cAMP was separated according to the method of Salomon (8) using Dowex 50- $\times 4$, 200-400 mesh (Bio-Rad Laboratories, Richmond, CA) and aluminum oxide (ICN, Cleveland, $\mathrm{OH}$ ) columns. Enzyme activity was expressed as femtomoles cAMP produced per millimiter per $30 \mathrm{~min}$. cAMP-Phosphodiesterase was assayed in a two step reaction (6). The first reaction was performed in a buffer containing $10 \mathrm{mM} \mathrm{MgSO}_{4}, 0.1 \mathrm{mM}$ EDTA, $50 \mathrm{mM}$ Tris, pH 8.0, and $1 \times 10^{-6} \mathrm{M}\left[{ }^{3} \mathrm{H}\right] \mathrm{cAMP}$ (New England Nuclear, Boston, MA) as a substrate. The reaction was carried out for $20 \mathrm{~min}$ at $37^{\circ} \mathrm{C}$ and the second reaction was performed with $1 \mathrm{mg} / \mathrm{ml} 5^{\prime}$-nucleotidase (snake venom [Naja Naja]; Calbiochem-Behring Corp., La Jolla, CA) for $10 \mathrm{~min}$ at $37^{\circ} \mathrm{C}$. The produced $\left[{ }^{3} \mathrm{H}\right]$ adenosine was separated chromatographically using QAE-Sephadex A-25 (Pharmacia Fine Chemicals, Piscataway, NJ) and counted.

Preparation of plasma membranes for AVP-binding studies. Renal papillary membranes were prepared from Sprague-Dawley rats weighing $200-250 \mathrm{~g}$ as described previously $(9,10)$. Briefly, the renal papilla was dissected and homogenized in Tris-sucrose buffer, pH 7.4 (250 mM sucrose, $3 \mathrm{mM} \mathrm{MgCl}, 1 \mathrm{mM}$ EDTA, and $5 \mathrm{mM}$ Tris), and centrifuged at $600 \mathrm{~g}$ for $10 \mathrm{~min}$. After centrifugation, the pellet was washed twice in hypoosmotic solution ( $3 \mathrm{mM} \mathrm{MgCl}, 1 \mathrm{mM}$ EDTA, and $5 \mathrm{mM}$ Tris, $\mathrm{pH}$ 7.4) to separate the membranes and then resuspended them in hypoosmotic solution. These membrane preparations were employed for the studies of ${ }^{3} \mathrm{H}$-AVP binding. The membranes were stored at $-80^{\circ} \mathrm{C}$ until the time of binding study; such freezing did not alter binding characteristics.

${ }^{3} \mathrm{H}-\mathrm{AVP}$ binding studies. ${ }^{3} \mathrm{H}-\mathrm{AVP}$ was a kind gift from SmithKline \& French Laboratories (Philadelphia, PA). The ${ }^{3} \mathrm{H}-\mathrm{AVP}$ was biologically active and the specific activity was $17 \mathrm{Ci} / \mathrm{mM}$. Binding of ${ }^{3} \mathrm{H}-\mathrm{AVP}$ to the renal papillary membranes was conducted by modified methods of Olefsky et al. (11) and Butlen et al. (12). The reaction medium contained $0.25 \mathrm{mM}$ creatine phosphate, $0.1 \mathrm{mg} / \mathrm{ml}$ creatine phosphokinase, $2.5 \%$ bovine serum albumin, $4 \mathrm{mM} \mathrm{MgCl}, 0.1 \mathrm{mM}$ EDTA, $0.5 \mathrm{mM}$ cAMP, and $40 \mathrm{mM}$ Tris buffer, $\mathrm{pH}$ 7.4.

Approximately $100 \mu \mathrm{g}$ of protein was used and the final volume was $100 \mu \mathrm{l}$. The reaction was started by addition of ${ }^{3} \mathrm{H}-\mathrm{AVP}$ with appropriate concentration, and incubated at $30^{\circ} \mathrm{C}$ for $15 \mathrm{~min}$. At the end of the incubation the tubes were placed in ice and vortexed, and immediately two 40- $\mu$ l samples of the mixture were carefully layered over cold 300 $\mu$ l of stopping solution ( $2.5 \%$ bovine serum albumin, $100 \mathrm{mM}$ Tris- $\mathrm{HCl}$, pH 7.4) in the Eppendorf microcentrifuge tube (Brinkman Instruments, Inc., Palo Alto, CA) at $2^{\circ} \mathrm{C}$ to $4^{\circ} \mathrm{C}$. After centrifugation, the supernatant solution was aspirated off under a bright illuminator. The pellet was carefully washed with cold $300 \mu$ l of washing solution (10\% sucrose, 100 $\mathrm{mM}$ Tris, $\mathrm{pH}$ 7.4) without disturbing the pellet. After aspiration of the washing solution, the tip of the microtube was cut at a point just above the pellet. The tip with pellet was transferred into a counting vial containing scintillation cocktail (Insta-gel [Packard Instrument Co., Inc., Downer's Grove, IL]) and counted in a Packard Tri-Carb $460 \mathrm{C}$ liquid scintillation counter. The nonspecific binding of ${ }^{3} \mathrm{H}-\mathrm{AVP}$ was determined in the presence of $10^{-5} \mathrm{M}$ AVP. The nonspecific binding at each concentration of ${ }^{3} \mathrm{H}$-AVP was not constant. As ${ }^{3} \mathrm{H}$-AVP increased the nonspecific binding was increased gradually also. For example, at $5 \times 10^{-9}$ $\mathrm{M}^{3} \mathrm{H}-\mathrm{AVP}$ the nonspecific binding was $8.8 \%$; at $1 \times 10^{-8} \mathrm{M}, 15.6 \%$; at $2.5 \times 10^{-8} \mathrm{M}, 21.4 \%$; at $5 \times 10^{-8} \mathrm{M}, 28.5 \%$; at $7.5 \times 10^{-8} \mathrm{M}, 48 \%$. The binding was linear up to $300 \mu \mathrm{g}$ of protein and reached maximum at 8 to $10 \mathrm{~min}$. Protein was measured by the modified method of Lowry et al. (13).
Study of net water flux across the isolated perfused rabbit CCT. Collecting tubular perfusion was carried out by slight modifications of the method developed by Burg et al. and Horster and Zink $(14,15)$. New Zealand white rabbits weighing $1-2 \mathrm{~kg}$ were maintained on rabbit chow (Purina, St. Louis, MO) and ad libitum water. The animals were killed by cervical dislocation and the left kidney was removed quickly. 1-2$\mathrm{mm}$ slices were cut along the cortico-medullary axis and placed in a

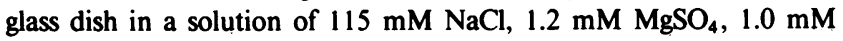
$\mathrm{CaCl}_{2}, 5.0 \mathrm{mM} \mathrm{KCl}, 10 \mathrm{mM}$ sodium acetate, $1.2 \mathrm{mM} \mathrm{NaH}_{2} \mathrm{PO}_{4}, 25$ $\mathrm{mM} \mathrm{NaHCO}$, and $5.5 \mathrm{mM}$ dextrose with $5 \%$ bovine serum albumin. This solution was maintained at $4^{\circ} \mathrm{C}$ and $\mathrm{pH}$ of 7.4 during dissection. The cortex was separated from outer medulla and CCT were dissected from medullary rays. Collecting tubules were identified by the presence of branching, straight configuration, light granular appearance with fuzzy borders, and generally open lumens. Tubules were taken distal to the last branch. Tubules were transferred to a lucite perfusion chamber (volume $\sim 2.0 \mathrm{ml}$ ) set on the stage of an inverted phase-contrast microscope (Olympus, Model CK, Tokyo, Japan).

Custom capillary glass (Drummond Scientific Co., Broomall, PA) was used to fashion (Stoelting Microforge, Chicago, IL) pipettes of required dimensions. Tubules were aspirated into the tip of a holding pipette (outer diameter $\sim 32-36 \mu \mathrm{m}$ ) up to a constriction of 16-18 $\mu \mathrm{m}$. A perfusion pipette $(\sim 12-14 \mu \mathrm{m})$ was advanced into the lumen and extended $50-100 \mu \mathrm{m}$ beyond the tip of the holding pipette. A large outer pipette containing Sylgard 184 (Dow Corning Corp., Midland, MI) was advanced over the tip of the holding pipette so that Sylgard covered the holding pipette and tubule up to the tip of the perfusion pipette. A fluid exchange pipette inside the perfusion pipette was used to change perfusate composition. The free end of the tubule was aspirated into a collection pipette, which had an inner diameter slightly less than the outer diameter of the tubule. The tip of the pipette was filled with Sylgard 184 and the tubule was aspirated through the Sylgard. Water equilibrated mineral oil was introduced into the collection pipette and a calibrated volumetric pipette (80-110 nl) was used to obtain precisely timed samples of constant volume. Samples were separated by mineral oil.

Tubules were bathed in the same solution used for dissection, except that no albumin was present. Bath fluid of $\mathrm{pH} 7.4$ and temperature of $25^{\circ} \mathrm{C} \mathrm{(16)} \mathrm{was} \mathrm{completely} \mathrm{changed} \mathrm{every} 5 \mathrm{~min}$. All studies were carried out at $25^{\circ} \mathrm{C}$ because the hydroosmotic response to vasopressin appears to be stable at this temperature (16). Tubules were perfused at rates of $5-15 \mathrm{nl} / \mathrm{min}$ by adjusting hydrostatic pressure of the fluid entering the fluid exchange pipette. Perfusion fluid composition was the same as bathing fluid, except that the final concentration of $\mathrm{NaCl}$ was reduced to $50 \mathrm{mM}$. This resulted in an approximate 100 -mOsm gradient from lumen to bathing fluid. Perfusion fluid contained a sufficient amount of ${ }^{14} \mathrm{C}$-inulin (New England Nuclear, Boston, MA) to result in collected fluid counts per minute 10 -fold above background $\mathrm{The}\left[\mathrm{C}^{14}\right]$ inulin was dissolved in perfusion solution a few minutes before use. Tubules were perfused for 150-180 min before studies were begun. The tubule was visually inspected throughout the duration of the study. Tubular length was measured at the conclusion of each study by a calibrated microscope eyepiece reticle.

Collected samples were placed under water equilibrated mineral oil in the bottom of a siliconized dish. 50-nl aliquots of these samples were taken for scintillation counting (Packard Tricarb 460C).

AVP was obtained from Parke Davis (Detroit, MI) in the form of Pitressin. This was diluted in bathing solution and frozen at $-4^{\circ} \mathrm{C}$ until use in a final concentration of $250 \mu \mathrm{U} / \mathrm{ml}$. AVP analogue was administered at $2.5 \times 10^{-7} \mathrm{M}$ in the bathing fluid.

Perfusion rate was calculated by the rate of appearance of the impermeant marker $\left[\mathrm{C}^{14}\right]$ inulin in the collection pipette according to the algorithm: Perfusion rate $=\left(\left[\mathrm{C}^{14}\right]_{\mathrm{c}}\right) /\left(\left[\mathrm{C}^{14}\right]_{\mathrm{p}}\right) \times$ collection rate, where $\left[\mathrm{C}^{14}\right]_{\mathrm{p}}$ equals $\mathrm{cpm}$ of perfusate and $\left[\mathrm{C}^{14}\right]_{c}$ equals $\mathrm{cpm}$ of collected fluid. Collection rate was measured directly with a calibrated volumetric pipette and stopwatch. Net volume of water reabsorption $\left(J_{\mathrm{v}}[\mathrm{nl} / \mathrm{mm} / \mathrm{min}]\right)$ was calculated as perfusion rate minus collection rate.

Hydraulic conductivity was calculated from the formula 


$$
L_{\mathrm{p}}=\frac{-V_{0} C_{0}}{R T A}\left[\frac{C_{0}-C_{\mathrm{L}}}{C_{0} C_{\mathrm{L}} C_{\mathrm{b}}}+\frac{1}{\left(C_{\mathrm{b}}\right)^{2}} \ln \frac{\left(C_{\mathrm{L}}-C_{\mathrm{b}}\right) C_{0}}{\left(C_{0}-C_{\mathrm{b}}\right) C_{\mathrm{L}}}\right] \mathrm{cm} / \mathrm{s} \cdot \mathrm{atm} \times 10^{-7},
$$

where $V_{0}$ is the perfusion rate in $\mathrm{cm}^{3} / \mathrm{s} ; C_{0}, C_{\mathrm{L}}$, and $C_{\mathrm{b}}$ are the osmotic concentrations of perfusate, collected fluid, and bathing medium, respectively; $R$ is the gas constant, $T$ is the absolute temperature, $A$ is the surface area (calculated from the length of the tubule and an average internal diameter of $20 \mu \mathrm{m}$ ), $L_{\mathrm{p}}$ is the hydraulic water conductivity in $\mathrm{cm} / \mathrm{s} \cdot \mathrm{atm}$. Osmolality of bathing fluid and perfusate were measured using an Advanced Osmometer. Collecting fluid osmolality was calculated as perfusate osmolality $X \mathrm{cpm}$ collected fluid/cpm perfused fluid.

Two groups of studies were performed. In eight tubules, collections were made for $30 \mathrm{~min}$ before and $50 \mathrm{~min}$ after AVP. In seven additional tubules, AVP analogue was given. Collections were made for $30 \mathrm{~min}$ after the analogue. At this point, AVP was given and additional collection for $\mathbf{4 0} \mathrm{min}$ after AVP were made. The two groups of tubules were perfused at $5-15 \mathrm{nl} / \mathrm{min}$ and their lengths averaged $0.95-1.0 \mathrm{~mm}$.

Another set of experiments were performed using each tubule as its own control to test the effect of AVP analogue on the AVP-stimulated $L_{\mathrm{p}}$. In these experiments AVP analogue $\left(2.5 \times 10^{-7} \mathrm{M}\right)$ was introduced into the bath for $\sim 1 \mathrm{~h}$. AVP $(250 \mu \mathrm{U} / \mathrm{ml})$ was then added to the bath. 30-40 min later the AVP analogue was removed from the bath. In our experience, AVP effects at this dose are maximal within 30-45 min. Comparisons were then made between tubular $L_{\mathrm{p}}$ in the presence of AVP analogue + AVP and AVP alone. test.

Statistics. The results were analyzed by using unpaired Student's $t$

\section{Results}

Effect of $d\left(\mathrm{CH}_{2}\right)_{5} \mathrm{Tyr}(\mathrm{Et}) \mathrm{VAVP}$ on the adenylate cyclase activation by $A V P$ PCT. As shown in Fig. $1,10^{-8} \mathrm{M}$ of $\mathrm{d}\left(\mathrm{CH}_{2}\right)_{5} \mathrm{Tyr}(\mathrm{Et})$ VAVP significantly inhibited the stimulation of adenylate cyclase at the various concentrations of AVP $\left(10^{-10}\right.$ to $10^{-6} \mathrm{M}$ ) in the rat renal PCT. $10^{-9} \mathrm{M} \mathrm{d}\left(\mathrm{CH}_{2}\right)_{5} \mathrm{Tyr}(\mathrm{Et}) \mathrm{VAVP}$ also significantly inhibited the adenylate cyclase stimulation by AVP concentrations from $10^{-9}$ to $10^{-8} \mathrm{M}$. Stimulation of adenylate cyclase by $5 \times 10^{-8}$ to $10^{-6} \mathrm{M}$ AVP was not significantly inhibited by $10^{-9} \mathrm{M}$ AVP. The basal activity was not changed in the presence of $10^{-8} \mathrm{Md}\left(\mathrm{CH}_{2}\right)_{5} \mathrm{Tyr}(\mathrm{Et}) \mathrm{VAVP}$.

$M C T$. Stimulation of adenylate cyclase by AVP in the MCT demonstrated the same dose response characteristics as in PCT, except that maximal stimulation of adenylate cyclase was reached

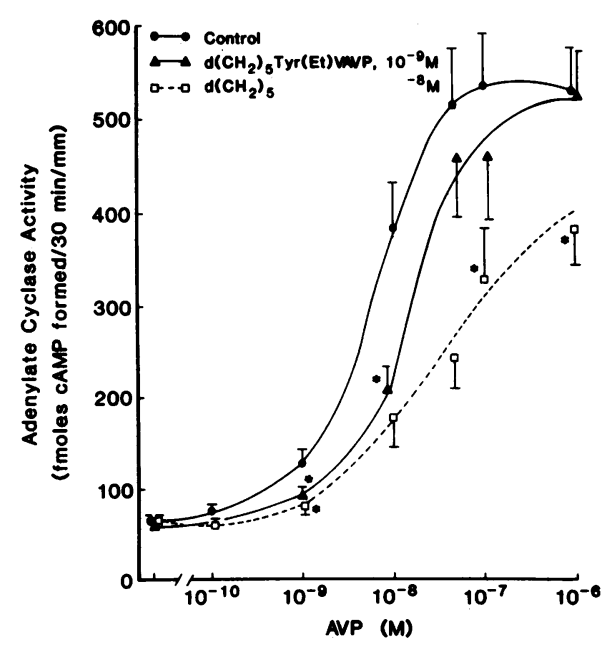

Figure 1. Effect of $\mathrm{d}\left(\mathrm{CH}_{2}\right)_{5} \mathrm{Tyr}(\mathrm{Et}) \mathrm{VAVP}$, diminishing profoundly the adenylate cyclase response to AVP in rat renal PCT $(n=8)$. *Significantly different from the control as $P$ value was $<0.05$ or lower. at $10^{-6} \mathrm{M}$ AVP (data not shown). At $10^{-8} \mathrm{M}$ AVP, adenylate cyclase was significantly stimulated as shown in Table $I .10^{-8}$ $\mathrm{M} \mathrm{d}\left(\mathrm{CH}_{2}\right)_{5} \mathrm{Tyr}(\mathrm{Et})$ VAVP did not affect the basal adenylate cyclase activity. In the presence of $10^{-8} \mathrm{Md}\left(\mathrm{CH}_{2}\right)_{5} \mathrm{Tyr}(\mathrm{Et}) \mathrm{VAVP}$, the stimulation of adenylate cyclase by $10^{-8} \mathrm{M}$ AVP was significantly inhibited.

$C C T$. Preliminary studies showed that the adenylate cyclase response to AVP in CCT is less sensitive than that in MCT or PCT in the rat, thus stimulation of CCT adenylate cyclase was assayed in the presence of $10^{-7} \mathrm{M}$ AVP. As shown in Table I, $10^{-7} \mathrm{M}$ AVP significantly increased adenylate cyclase. $\mathrm{d}\left(\mathrm{CH}_{2}\right)_{5} \mathrm{Tyr}(\mathrm{Et}) \mathrm{VAVP}$ at $10^{-7} \mathrm{M}$ completely blocked the stimulation of adenylate cyclase by AVP.

Salmon calcitonin (SCT), in both maximal $\left(3 \times 10^{-7} \mathrm{M}\right)$ or submaximal stimulatory concentration $\left(1.5 \times 10^{-8} \mathrm{M}\right)$, significantly increased the adenylate cyclase in CCT, and $10^{-6} \mathrm{M}$ $\mathrm{d}\left(\mathrm{CH}_{2}\right)_{5} \mathrm{Tyr}(\mathrm{Et})$ VAVP did not affect the stimulation of adenylate cyclase by SCT (Table II).

$M A L$. The adenylate cyclase in MAL from the rats that were used for studies of collecting tubules (Charles River SpragueDawley, Wilmington, MA) did not respond to AVP. A different strain of Sprague-Dawley rats (Harlan Rats, Indianapolis, IN) were used in the study of MAL. The adenylate cyclase response to AVP in the collecting tubules was the same in the Charles River and Harlan rats (17).

AVP $\left(10^{-6} \mathrm{M}\right)$ significantly stimulated adenylate cyclase as shown in Table I. d( $\left.\mathrm{CH}_{2}\right)_{5}$ Tyr(Et)VAVP itself did not show any effect on the basal adenylate cyclase activity at a concentration of $10^{-6} \mathrm{M}$. This AVP analogue significantly inhibited the stimulation of adenylate cyclase by $10^{-6} \mathrm{M}$ AVP.

Glucagon $\left(10^{-8}\right.$ and $\left.10^{-6} \mathrm{M}\right)$ also significantly stimulated adenylate cyclase in MAL of rat as shown in Table II. $\mathrm{d}\left(\mathrm{CH}_{2}\right)_{5}$ Tyr(Et)VAVP did not inhibit the stimulation of adenylate cyclase by submaximal $\left(10^{-8} \mathrm{M}\right)$ and maximal $\left(10^{-6}\right)$ stimulatory concentrations of glucagon.

$C A L$. The absence of an effect of $\mathrm{d}\left(\mathrm{CH}_{2}\right)_{5} \mathrm{Tyr}(\mathrm{Et}) \mathrm{VAVP}$ to alter the stimulation of adenylate cyclase by PTH in the CAL is shown in Table II. PTH ( 1 and $10 \mathrm{IU} / \mathrm{ml}$ ) significantly increased the adenylate cyclase, and $10^{-7} \mathrm{M} \mathrm{d}\left(\mathrm{CH}_{2}\right)_{5} \mathrm{Tyr}(\mathrm{Et}) \mathrm{VAVP}$ had no effect on this activation of adenylate cyclase by either concentration of PTH in CAL.

Effect of $d\left(\mathrm{CH}_{2}\right)_{5} \mathrm{Ty}(\mathrm{Et}) \mathrm{VAVP}$ on cAMP-phosphodiesterase in the PCT. cAMP-phosphodiesterase activity in the PCT was measured in the presence of $10^{-8} \mathrm{M} \mathrm{d}\left(\mathrm{CH}_{2}\right)_{5} \mathrm{Tyr}(\mathrm{Et}) \mathrm{VAVP}$, a concentration that completely blocked the stimulation of adenylate cyclase by AVP in PCT. The AVP analogue did not alter the activity of cAMP-phosphodiesterase in the PCT (basal $9.30 \pm 0.62 ;+10^{-8} \mathrm{M}$ AVP analogue $8.89 \pm 0.86 \mathrm{fmol} / \mathrm{min} / \mathrm{mm}$, $n=5$, NS).

Studies of ${ }^{3} \mathrm{H}-\mathrm{AVP}$ binding to renal papillary plasma membranes. ${ }^{3} \mathrm{H}$-AVP binding to the renal papillary membranes was studied in the absence and presence of $10^{-9}, 10^{-7}$, and $10^{-6} \mathrm{M}$ AVP analogue. ${ }^{3} \mathrm{H}$-AVP binding to the renal papillary membranes was dose-dependent when the specific ${ }^{3} \mathrm{H}$-AVP binding was plotted as a function of the ${ }^{3} \mathrm{H}$-AVP concentration in the incubation medium (Fig. 2). $10^{-6} \mathrm{M} \mathrm{d}\left(\mathrm{CH}_{2}\right)_{5} \mathrm{Tyr}(\mathrm{Et}) \mathrm{VAVP}$ almost completely blocked the ${ }^{3} \mathrm{H}-\mathrm{AVP}$ binding to the renal papillary membranes. $10^{-7} \mathrm{M}$ AVP analogue significantly inhibited the ${ }^{3} \mathrm{H}-\mathrm{AVP}$ binding to the renal papillary membranes at the various concentrations of ${ }^{3} \mathrm{H}$-AVP. In the curve with $10^{-7} \mathrm{M}$ AVP analogue, ${ }^{3} \mathrm{H}$-AVP binding at $10^{-9}$ to $2.5 \times 10^{-8} \mathrm{M}^{3} \mathrm{H}$ AVP was almost completely blocked, then the inhibitory 
Table I. Effect of $d\left(\mathrm{CH}_{2}\right)_{5} \mathrm{Tyr}(\mathrm{Et}) V A V P$ on the Adenylate Cyclase Response to $A V P$ in the Rat Renal CCT, MCT, and PCT (fmol cAMP formed $/ 30 \mathrm{~min} / \mathrm{mm}$ )

\begin{tabular}{|c|c|c|c|c|c|c|c|}
\hline & Basal & AVP* & $\begin{array}{l}P \text { value: } \\
\text { basal vs. } \\
\text { AVP }\end{array}$ & Antagonist & $\begin{array}{l}\text { AVP } \\
+ \text { antagonist* }\end{array}$ & $\begin{array}{l}P \text { value: } \\
\text { antagonist } \\
\text { vs. AVP } \\
+ \text { antagonist }\end{array}$ & $\begin{array}{l}P \text { value AVP } \\
\text { vs. AVP } \\
+ \text { antagonist }\end{array}$ \\
\hline $\mathrm{CCT}(n=6)$ & $13.42 \pm 1.21$ & $37.39 \pm 5.25$ & $<0.005$ & $14.52 \pm 0.81$ & $17.37 \pm 1.97$ & NS & $<0.02$ \\
\hline $\operatorname{MCT}(n=5)$ & $26.67 \pm 4.40$ & $132.23 \pm 18.96$ & $<0.001$ & $32.07 \pm 5.72$ & $51.03 \pm 7.24$ & NS & $<0.02$ \\
\hline $\operatorname{MAL}(n=6)$ & $7.42 \pm 0.92$ & $43.75 \pm 4.58$ & $<0.001$ & $8.90 \pm 0.89$ & $15.44 \pm 4.72$ & NS & $<0.005$ \\
\hline
\end{tabular}

Each value represents means \pm SEM. ${ }^{*} \mathrm{CCT}, 10^{-7} \mathrm{M} ; \mathrm{MCT}, 10^{-8} \mathrm{M} ; \mathrm{MAL} 10^{-6} \mathrm{M}$.

action was less potent as the ${ }^{3} \mathrm{H}$-AVP concentration was increased to a concentration $>5 \times 10^{-8} \mathrm{M}{ }^{3} \mathrm{H}$-AVP. $10^{-9} \mathrm{M}$ $\mathrm{d}\left(\mathrm{CH}_{2}\right)_{5} \mathrm{Tyr}(\mathrm{Et}) \mathrm{VAVP}$ significantly inhibited the ${ }^{3} \mathrm{H}-\mathrm{AVP}$ binding at $10^{-9}$ to $10^{-8} \mathrm{M}^{3} \mathrm{H}-\mathrm{AVP}$; however, the inhibition was not significantly different at $>2.5 \times 10^{-8} \mathrm{M}{ }^{3} \mathrm{H}-\mathrm{AVP} . K_{\mathrm{i}}$ of the AVP analogue was $9 \times 10^{-9} \mathrm{M}$.

Study of net water flux across the isolated perfused rabbit $C C T$. The effect of AVP on hydraulic conductivity in the presence and absence of the analogue is depicted in Fig. 3. $\mathrm{d}\left(\mathrm{CH}_{2}\right)_{s} \mathrm{Tyr}(\mathrm{Et})$ VAVP exerted a transient effect to increase $L_{\mathrm{p}}$ $\left(30 \pm 17\right.$ to $\left.70 \pm 14 \mathrm{~cm} / \mathrm{s} \cdot \mathrm{atm} \times 10^{-7}\right)$. This increase in $L_{\mathrm{p}}$ after the AVP analogue was observed in the first or second collection period after the analogue, thereafter $L_{\mathrm{p}}$ returned to basal levels. Because of the transient agonist effect of the AVP analogue, AVP was administered 40-50 min after the tubules had been bathed in the analogue. AVP increased $L_{\mathrm{p}}$ from 25 to $95 \mathrm{~cm} /$ $\mathrm{s} \cdot \mathrm{atm} \times 10^{-7}(P<0.02)$ in tubules not pretreated with the AVP analogue. In contrast, no significant increase in $L_{p}$ was observed when AVP was administered to tubules bathed with the AVP analogue.

In the paired CCT experiments, $J_{\mathrm{v}}$ with AVP analogue alone $(0.25 \pm 0.09 \mathrm{nl} / \mathrm{mm} \cdot \mathrm{min})$ was not significantly different from
AVP analogue + AVP $(0.05 \pm 0.09 \mathrm{nl} / \mathrm{mm} \cdot \mathrm{min})$. The comparison between AVP analogue + AVP and AVP alone is shown in Fig. 4. Each line in the figure connects $L_{\mathrm{p}}$ obtained from a single tubule in the presence of AVP analogue + AVP (mean $8.7 \pm 5.0 \times 10^{-7} \mathrm{~cm} / \mathrm{s} \cdot \mathrm{atm}$ ) with the $L_{\mathrm{p}}$ of that same tubule after the AVP analogue was removed from the bath (mean $79 \pm 41$ $\left.\times 10^{-7} \mathrm{~cm} / \mathrm{s} \cdot \mathrm{atm}\right)$. As can be seen AVP analogue significantly inhibited the effects of AVP until the AVP analogue was removed from the bath $(P<0.05)$.

\section{Discussion}

In this present study the cellular action of a newly synthesized AVP analogue, $\mathrm{d}\left(\mathrm{CH}_{2}\right)_{5} \mathrm{Tyr}(\mathrm{Et}) \mathrm{VAVP}$, was examined. This analogue has been shown in vivo to block the antidiuretic effect of AVP in the anesthetized and conscious rat $(2,3)$. The AVP analogue has also been shown to inhibit AVP binding to pig and human medullopapillary membranes $(4,5)$. In these medullopapillary membrane preparations the effect of the AVP analogue on the MAL, MCT, or PCT cannot be differentiated.

In the present studies, ${ }^{3} \mathrm{H}-\mathrm{AVP}$ binding studies were performed in rat papillary membranes that should not contain re-

Table II. Effect of AVP Antagonist, d $\left(\mathrm{CH}_{2}\right)_{5} \mathrm{Tyr}(\mathrm{Et}) \mathrm{VAVP}$, on the Adenylate Cyclase Response to $P T H$, Calcitonin, and Glucagon in the Rat Renal CAL, CCT, and MAL (fmol cAMP formed/30 min/mm)

\begin{tabular}{|c|c|c|c|c|c|c|c|c|c|}
\hline & Basal & Hormones & & $\begin{array}{l}P \text { value: } \\
\text { basal vs. } \\
\text { hormones }\end{array}$ & Antagonist* & Hormones + ant & nist! & $\begin{array}{l}P \text { value: } \\
\text { antagonist vs. } \\
\text { hormones } \\
+ \text { antagonist }\end{array}$ & $\begin{array}{l}P \text { value: } \\
\text { hormones vs. } \\
\text { hormones } \\
\text { antagonist }\end{array}$ \\
\hline & & $\begin{array}{l}+ \text { PTH } \\
10 \mathrm{IU} / \mathrm{ml}\end{array}$ & $1 \mathrm{IU} / \mathrm{ml}$ & & & $\begin{array}{l}+ \text { PTH } \\
10 \mathrm{IU} / \mathrm{ml}\end{array}$ & $1 \mathrm{IU} / \mathrm{ml}$ & & \\
\hline \multirow{3}{*}{$\begin{array}{l}\mathrm{CAL} \\
n=6\end{array}$} & $16.71 \pm 1.38$ & $344.09 \pm 37.01$ & & $<0.001$ & $17.55 \pm 1.67$ & $338.47 \pm 39.31$ & & $<0.001$ & NS \\
\hline & & & $102.06 \pm 11.16 \ddagger$ & $<0.001$ & & & $112.40 \pm 18.35 \ddagger$ & $<0.001$ & NS \\
\hline & & $\begin{array}{l}+ \text { Calcitonin } \\
3 \times 10^{-1} \mathrm{M}\end{array}$ & $1.5 \times 10^{-8} \mathrm{M}$ & & & $\begin{array}{l}\text { + Calcitonin } \\
3 \times 10^{-1} \mathrm{M}\end{array}$ & $1.5 \times 10^{-8} \mathrm{M}$ & & \\
\hline \multirow{3}{*}{$\begin{array}{l}\text { CCT } \\
n=6\end{array}$} & $35.10 \pm 8.53$ & $242.81 \pm 15.80$ & & $<0.001$ & $35.80 \pm 8.60$ & $255.31 \pm 23.69$ & & $<0.001$ & NS \\
\hline & & & $100.92 \pm 15.78 \ddagger$ & $<0.005$ & & & $86.27 \pm 12.65 \ddagger$ & $<0.001$ & NS \\
\hline & & $\begin{array}{l}+ \text { Glucagon } \\
10^{-6} \mathrm{M}\end{array}$ & $10^{-8} \mathrm{M}$ & & & $\begin{array}{l}+ \text { Glucagon } \\
10^{-6} \mathrm{M}\end{array}$ & $10^{-8} \mathrm{M}$ & & \\
\hline \multirow{2}{*}{$\begin{array}{l}\text { MAL } \\
\quad n=5\end{array}$} & $7.18 \pm 1.00$ & $211.88 \pm 29.07$ & & $<0.001$ & $6.76 \pm 1.03$ & $219.98 \pm 27.60$ & & $<0.001$ & NS \\
\hline & & & $58.42 \pm 10.09 \ddagger$ & $<0.001$ & & & $68.00 \pm 10.49 \ddagger$ & $<0.001$ & NS \\
\hline
\end{tabular}

Each value represents mean $\pm \mathrm{SEM} .{ }^{*} \mathrm{CAL} 10^{-7} \mathrm{M}, \mathrm{CCT} 10^{-6} \mathrm{M} . \ddagger P$ value, maximal vs. submaximal concentrations of hormones; $<0.001$. 


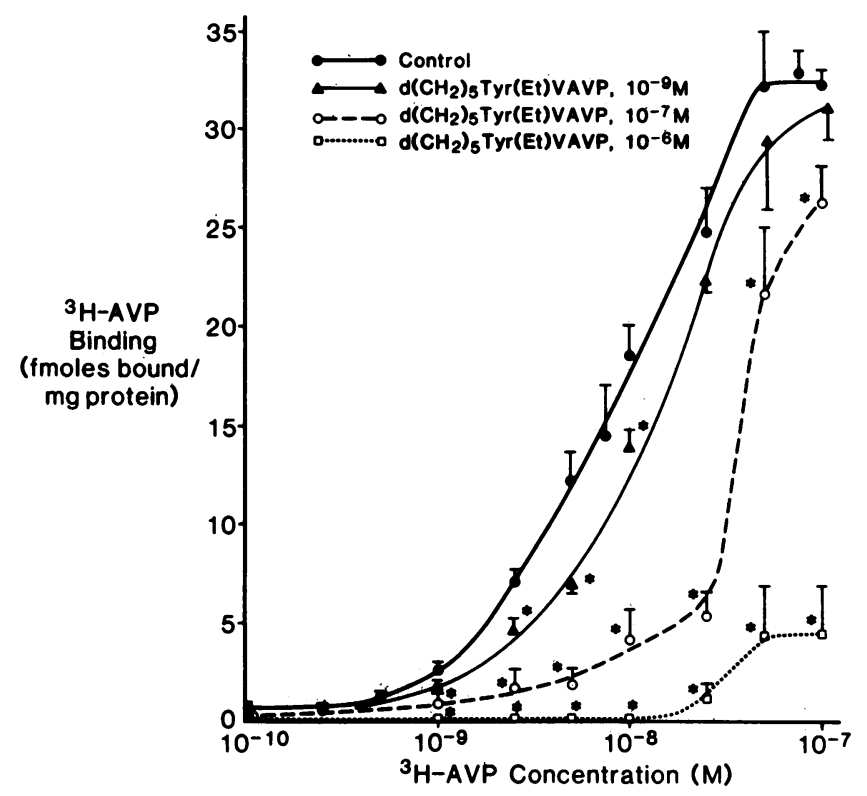

Figure 2. Diminution of ${ }^{3} \mathrm{H}-\mathrm{AVP}$ binding to rat renal papillary membranes in the absence or presence of AVP analogue,

$\mathrm{d}\left(\mathrm{CH}_{2}\right)_{5} \mathrm{Tyr}(\mathrm{Et}) \operatorname{VAVP}(n=7)$. The specific ${ }^{3} \mathrm{H}-\mathrm{AVP}$ binding is plotted as a function of ${ }^{3} \mathrm{H}-\mathrm{AVP}$ concentration in the incubation medium. Each point represents mean \pm SEM. *Significantly different from the control as $P$ value was $<0.05$ or lower.

ceptor sites of AVP action on the MAL or MCT. In these studies, the dissociation constant in the renal papillary membrane $(1.4$ $\times 10^{-8} \mathrm{M}$ ) was similar to that observed in human medullopapillary membranes $\left(1.6 \times 10^{-8} \mathrm{M}\right)(5)$. The apparent inhibition constants $\left(\mathrm{K}_{\mathrm{i}}\right)$ of $\mathrm{d}\left(\mathrm{CH}_{2}\right)_{5} \mathrm{Tyr}(\mathrm{Et}) \mathrm{VAVP}$ in rat papillary membranes $\left(9 \times 10^{-9} \mathrm{M}\right)$ was also similar to that observed in medullopapillary membranes of human $\left(5.9 \times 10^{-9} \mathrm{M}\right)(5)$.

The earlier results using renal medullopapillary membranes $(4,5)$ were compatible with a competitive antagonism as the cellular action of $\mathrm{d}\left(\mathrm{CH}_{2}\right)_{5} \mathrm{Tyr}(\mathrm{Et}) \mathrm{VAVP}$. In the present study (Fig. 2), the curve of ${ }^{3} \mathrm{H}$-AVP binding in the presence of $10^{-7}$ $\mathrm{M} \mathrm{d}\left(\mathrm{CH}_{2}\right)_{5}$ Tyr(Et)VAVP demonstrated less inhibition of ${ }^{3} \mathrm{H}$ AVP binding at higher concentrations of ${ }^{3} \mathrm{H}-\mathrm{AVP}\left(5 \times 10^{-8}\right.$ and $10^{-7} \mathrm{M}$ AVP) than at lower concentrations. This suggests that the inhibitory effect of $d\left(\mathrm{CH}_{2}\right)_{5} \mathrm{Tyr}(\mathrm{Et})$ VAVP can be overcome at higher ${ }^{3} \mathrm{H}$-AVP concentrations; thus supporting a competitive nature of the antagonism. Doses $>10^{-7} \mathrm{M}^{3} \mathrm{H}-\mathrm{AVP}$ could not

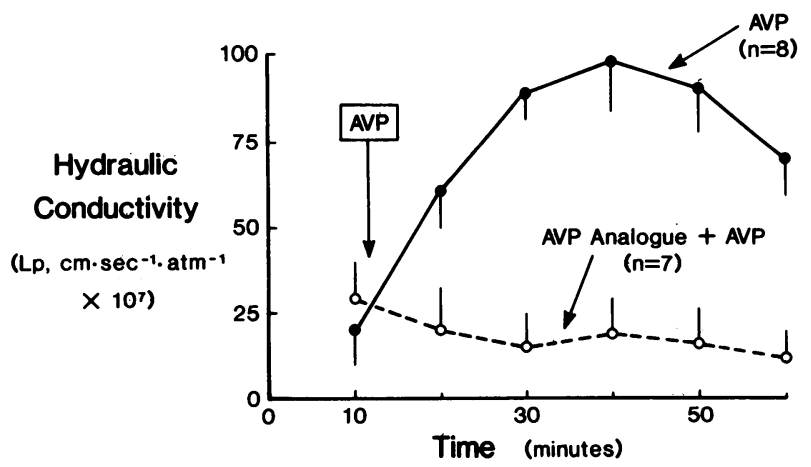

Figure 3. Effect of $\mathrm{d}\left(\mathrm{CH}_{2}\right)_{5} \operatorname{Tyr}(\mathrm{Et}) \operatorname{VAVP}\left(10^{-7} \mathrm{M}\right)$, abolishing the effect of AVP $(250, \mu \mathrm{U} / \mathrm{ml})$ on hydraulic conductivity $\left(L_{\mathrm{p}}\right)$ in the rabbit CCT. Each point represents mean \pm SEM.

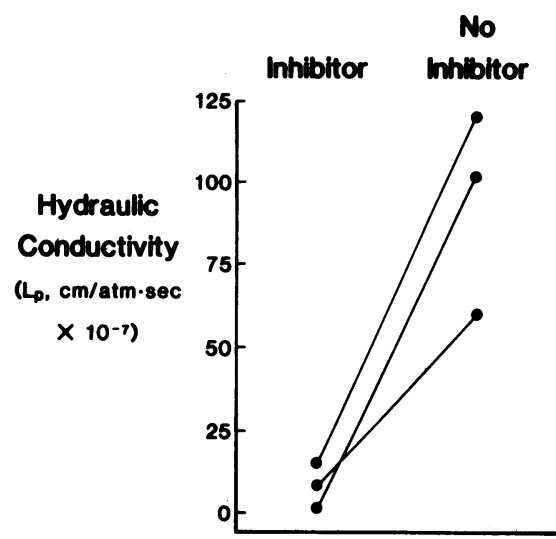

Figure 4. AVP-stimulated hydraulic conductivity, $L_{\mathrm{p}}$, in the presence or absence of d($\left(\mathrm{CH}_{2}\right)_{5} \mathrm{Tyr}(\mathrm{Et}) \mathrm{VAVP}$. AVP, $250 \mu \mathrm{U} / \mathrm{ml}$. d( $\left(\mathrm{CH}_{2}\right)_{5} \mathrm{Tyr}-$ (Et)VAVP (shown as inhibitor), $2.5 \times 10^{-7} \mathrm{M}$. Three lines represent experiments of CCT from three different rabbits.

be used because of too high and irregular nonspecific binding. The dose response curve of adenylate cyclase response to AVP in the papillary collecting tubule in the presence of AVP analogue showed the same pattern as ${ }^{3} \mathrm{H}-\mathrm{AVP}$. Specifically, AVP $\left(10^{-6}\right.$ M) was shown to overcome the antagonist's effect $\left(10^{-9} \mathrm{M}\right)$ to inhibit the stimulation of adenylate cyclase in the rat renal papillary collect duct. Taken together, these results support competitive antagonism as the cellular mechanism of action of the antagonist.

To identify the specific nephron sites of action of the AVP analogue, we investigated its effect on activation of adenylate cyclase by AVP in various segments of the nephron. The AVP analogue was shown to diminish the activation of adenylate cyclase in the PCT in a dose-response manner. Since AVP is known also to act in the MCT and CCT, studies were performed in these dissected segments of the rat nephron. In these studies the AVP analogue also blocked the effect of AVP to stimulate adenylate cyclase. Since the adenylate cyclase is more sensitive in the PCT than MCT and CCT (unpublished observations), different concentrations of AVP and the AVP analogue were used in the separate segments. Since AVP has been shown to activate adenylate cyclase in the MAL in some species, including the rat $(6,19-25)$, the effect of the analogue in this nephron segment was also examined. The stimulation of adenylate cyclase by AVP in MAL, MCT, and CCT were also inhibited by this analogue, indicating that this AVP analogue has effects on the same nephron sites where AVP acts.

The in vitro specificity of the analogue for AVP was further examined in a group of studies using submaximal and maximal stimulatory concentrations of several hormones known to stimulate adenylate cyclase in various segments of the rat nephron. These results confirmed the specificity of the AVP analogue for AVP sites of action in nephron. Specifically, the AVP analogue did not alter the stimulation of adenylate cyclase by PTH in the CAL, by calcitonin in the CCT, or by glucagon in the MAL.

These in vitro studies were compatible, therefore, with the in vivo observations $(2,3)$ that the effect of $A V P$ on tubular epithelium is directly antagonized by this recently synthesized AVP analogue. Although there are in vivo factors that could alter water excretion independent of a direct cellular antagonism of AVP, including increases in glomerular filtration rate, solute excretion, and blood pressure, in an earlier study these factors 
were excluded (3). Further evidence for a direct cellular effect was obtained by examining the in vitro antagonism by the analogue on AVP-induced water flux in the isolated CCT. The results demonstrated that the effect of AVP to increase hydraulic conductivity and to enhance osmotic water flux across the isolated perfused cortical tubule of the rabbit was abolished by the AVP analogue. The early (10-min) transient agonistic effect of the AVP analogue seen in the hydraulic conductivity of CCT was also observed in the in vivo study (3). This transient agonistic effect of the AVP analogue was not demonstrable on the adenylate cyclase response of collecting tubules, since the in vitro enzyme assay was conducted after a 30 -min, fixed reaction time period.

Thus, the present in vitro studies demonstrated effects of the AVP analogue to $(a)$ diminish AVP binding in rat papillary membranes, $(b)$ decrease adenylate cyclase activation in the rat MAL as well as the CCT, MCT, and PCT, $(c)$ not alter the specific effects of PTH, calcitonin, and glucagon on adenylate cyclase activation in specific rat nephron segments, and $(d)$ to block the effect of AVP to increase hydraulic conductivity and water flux on isolated perfused CCT of the rabbit. Evidence is presented for competitive antagonism as the cellular mechanism of action. This analogue has also been recently shown in vivo to reverse the water retention associated with either glucocorticoid or mineralocorticoid deficiency in the adrenally insufficient conscious rat (26). There is, thus, potential clinical and experimental use for this exciting new AVP analogue.

\section{Acknowledgments}

The authors are very grateful to Drs. Maurice Manning and Wilbur $\mathbf{H}$. Sawyer for supplying us the AVP analogue. ${ }^{3} \mathrm{H}$-AVP was a kind gift from Smith-Kline and French Laboratories. The authors wish to thank Linda M. Benson for secretarial assistance.

This work was supported by National Institutes of Health grant AM 19928.

\section{References}

1. Manning, M., B. Lammek, A. M. Kolodziejczyk, J. Seto, and W. H. Sawyer. 1981. Synthetic antagonists of in vivo antidiuretic and vasopressor responses to arginine vasopressin. J. Med. Chem. 24:701706.

2. Sawyer, W. H., P. K. T. Pang, J. Seto, M. McEnroe, B. Lammek, and M. Manning. 1981. Vasopressin analogs that antagonize antidiuretic responses by rats to the antidiuretic hormone. Science (Wash. DC). 212: 49-51.

3. Ishikawa, S., J. K. Kim, and R. W. Schrier. 1983. Further in vivo evidence for antagonist to hydroosmotic action of arginine vasopressin. Am. J. Physiol. 245:R713-R719.

4. Stassen, F. L., R. W. Erickson, W. F. Huffman, J. S. Stefankiewicz, L. Sulat, and V. D. Wiebelhaus. 1982. Molecular mechanisms of novel antidiuretic antagonists: analysis of the effects on vasopressin binding and adenylate cyclase activation in animal and human kidney. J. Pharmacol. Exp. Ther. 223:50-54.

5. Guillon, G., D. Butlen, B. Cantau, T. Barth, and S. Jard. 1982. Kinetic and pharmacological characterization of vasopressin membrane receptors from human kidney medulla: relation to adenylate cyclase activation. Eur. J. Pharmacol. 85:291-304.

6. Kim, J. K., B. A. Jackson, R. M. Edwards, and T. P. Dousa. 1982. Effect of potassium depletion on the vasopressin-sensitive cyclic AMP system in rat outer medullary tubules. J. Lab. Clin. Med. 99:29-38.

7. Morel, F., D. Chabardes, and M. Imbert-Teboul. 1976. Method- ology for enzymatic studies of isolated tubular segments: adenylate cyclase. Methods Pharmacol. 4(B):297-323.

8. Salomon, Y. 1979. Adenylate cyclase assay. Adv. Cyclic Nucleotide Res. 10:35-55.

9. Kim, J. K., P. P. Frohnert, Y. S. F. Hui, L. D. Barnes, G. M. Farrow, and T. P. Dousa. 1977. Enzymes of cyclic 3',5'-nucleotide metabolism in human renal cortex and renal adenocarcinoma. Kidney Int. 12:172-183.

10. Harkcom, T. M., J. K. Kim, P. J. Palumbo, Y. S. F. Hui, and T. P. Dousa. 1978. Modulatory effect of thyroid function on enzymes of vasopressin-sensitive cyclic AMP system in renal medulla. Endocrinology. 102:1475-1484.

11. Olefsky, J. M., J. Johnson, F. Liu, P. Edwards, and S. Bauer. 1975. Comparison of ${ }^{125}$ I-insulin binding and degradation to isolated rat hepatocytes and liver membranes. Diabetes. 24:801-810.

12. Butlen, D., G. Gilles, R. M. Rajerison, S. Jard, W. H. Sawyer, and M. Manning. 1978. Structural requirements for activation of vasopressin-sensitive adenylate cyclase, hormone binding, and antidiuretic actions: effects of highly potent analogues and competitive inhibitors. Mol. Pharmacol. 14:1006-1017.

13. Lowry, O. H., N. J. Rosenbrough, A. L. Farr, and R. J. Randall. 1951. Protein measurement with the Folin phenol reagent. J. Biol. Chem. 193:265-275.

14. Burg, M., J. Grantham, M. Abramow, and J. Orloff. 1966. Preparation and study of fragments of single rabbit nephrons. Am. J. Physiol. 210:1293-1298.

15. Horster, M. F., and H. Zink. 1982. Functional differentiation of the medullary collecting tubule: influence of vasopressin. Kidney Int. 22:360-365.

16. Hall, D. A., and J. J. Grantham. 1980. Temperature effect on ADH response of isolated perfused rabbit collecting tubules. Am. J. Physiol. 239:F595-F601.

17. Kim, J. K., S. N. Summer, A. E. Erickson, and R. W. Schrier. 1984. Effect of arginine vasopressin (AVP) on the renal medullary thick ascending limb (MAL) in the maximal concentrating ability of the rat. IX International Congress on Nephrology. 419A. (Abstr.)

18. Lindberg, G., H. Vilhardt, L. E. Larsson, P. Melin, and V. Pliska. 1980. Effect of O-alkylated analogue of lysine vasopressin on adenylate cyclase of pig kidney membranes. J. Recept. Res. 1:389-402.

19. Morel, F. 1981. Sites of hormone action in the mammalian nephron. Am. J. Physiol. 240:F159-F164.

20. Morel, F., D. Chabardès, and M. Imbert-Teboul. 1976. A functional segmentation of the rabbit distal tubule by microdetermination of hormone-dependent adenylate cyclase activity. Kidney Int. 9:264277.

21. Imbert-Teboul, M., D. Chabardès, M. Montégut, A. Clique, and F. Morel. 1978. Vasopressin-dependent adenylate cyclase activities in the rat kidney medulla: evidence for two separate sites of action. Endocrinology. 102:1254-1261.

22. Chabardès, D., M. Gagnan-Brunette, M. Imbert-Teboul, $O$. Gontcharevskalia, M. Montégut, A. Clique, and F. Morel. 1980. Adenylate cyclase responsiveness to hormones in various portions of the human nephron. J. Clin. Invest. 65:439-448.

23. Chabardès, D., M. Imbert-Teboul, M. Gagnan-Brunette, and F. Morel. 1978. Different hormonal sites along the mouse and rabbit nephrons. In Biochemical Nephrology. W. G. Guder and U. Schmidt, editors. Huber, Bern, Federal Republic of Germany. 447-454.

24. Hall, D. A., and D. M. Varney. 1980. Effect of vasopressin on electrical potential difference and chloride transport in mouse medullary thick ascending limb of Henle's loop. J. Clin. Invest. 66:792-802.

25. Sasaki, S., and M. Imai. 1980. Effects of vasopressin on water and $\mathrm{NaCl}$ transport across in vitro perfused medullary thick ascending limb of Henle's loop of mouse, rat and rabbit kidneys. Pflügers Arch. Eur. J. Physiol. 383:215-221.

26. Ishikawa, S., and R. W. Schrier. 1982. Effect of arginine vasopressin antagonist on renal water excretion in glucocorticoid and mineralocorticoid deficient rats. Kidney Int. 22:587-593. 